\title{
Climate Change Implications for Tidal Marshes and Food Web Linkages to Estuarine and Coastal Nekton
}

\author{
Denise D. Colombano ${ }^{1}$ (D) Steven Y. Litvin ${ }^{2}$. Shelby L. Ziegler ${ }^{3} \cdot$ Scott B. Alford ${ }^{4} \cdot$ Ronald Baker $^{5}$. \\ Myriam A. Barbeau ${ }^{6}$. Just Cebrián ${ }^{7} \cdot$ Rod M. Connolly ${ }^{8} \cdot$ Carolyn A. Currin $^{9} \cdot$ Linda A. Deegan $^{10}$ - Justin S. Lesser ${ }^{11}$. \\ Charles W. Martin ${ }^{4}$. Ashley E. McDonald ${ }^{12}$. Catherine McLuckie ${ }^{13}$ - Blair H. Morrison ${ }^{5}$. James W. Pahl ${ }^{14}$. \\ L. Mark Risse ${ }^{15} \cdot$ Joseph A. M. Smith ${ }^{16} \cdot$ Lorie W. Staver $^{17} \cdot$ R. Eugene Turner ${ }^{18} \cdot$ Nathan J. Waltham ${ }^{19}$
}

Received: 2 September 2020 /Revised: 16 December 2020 / Accepted: 21 December 2020 / Published online: 21 January 2021

(C) The Author(s) 2021

\begin{abstract}
Climate change is altering naturally fluctuating environmental conditions in coastal and estuarine ecosystems across the globe. Departures from long-term averages and ranges of environmental variables are increasingly being observed as directional changes [e.g., rising sea levels, sea surface temperatures (SST)] and less predictable periodic cycles (e.g., Atlantic or Pacific decadal oscillations) and extremes (e.g., coastal flooding, marine heatwaves). Quantifying the short- and long-term impacts of climate change on tidal marsh seascape structure and function for nekton is a critical step toward fisheries conservation and management. The multiple stressor framework provides a promising approach for advancing integrative, cross-disciplinary research on tidal marshes and food web dynamics. It can be used to quantify climate change effects on and interactions between coastal oceans (e.g., SST, ocean currents, waves) and watersheds (e.g., precipitation, river flows), tidal marsh geomorphology (e.g., vegetation structure, elevation capital, sedimentation), and estuarine and coastal nekton (e.g., species distributions, life history adaptations, predator-prey dynamics). However, disentangling the cumulative impacts of multiple interacting stressors on tidal marshes, whether the effects are additive, synergistic, or antagonistic, and the time scales at which they occur, poses a significant research challenge. This perspective highlights the key physical and ecological processes affecting tidal marshes, with an emphasis on the trophic linkages between marsh production and estuarine and coastal nekton, recommended for consideration in future climate change studies. Such studies are urgently needed to understand climate change effects on tidal marshes now and into the future.
\end{abstract}

Keywords Tidal wetlands $\cdot$ Seascapes $\cdot$ Multiple stressors $\cdot$ Ecosystem resilience $\cdot$ Trophic relays

\section{Introduction}

Tidal marshes are vegetated intertidal habitats that occur at the land-sea interface and thus serve as critical transition zones linking marine, freshwater, and terrestrial processes (Boström et al. 2011). Recent research demonstrates the urgent need to understand both short- and long-term impacts of climate change and sea level rise (SLR) on tidal marsh ecosystem function, food webs, and fisheries support (Able this issue;

Communicated by Charles T. Roman

Denise D. Colombano

denise.colombano@berkeley.edu

Extended author information available on the last page of the article
Baker et al. 2020; Gilby et al. 2020). The cumulative impacts of multiple interacting stressors, and whether the net effects are additive, synergistic, or antagonistic, are receiving increased attention in the ecological literature (Crain et al. 2008; Przeslawski et al. 2015; Jackson et al. 2016; Lauchlan and Nagelkerken 2020). To further advance this area of research, we revisit established concepts published in Concepts and Controversies in Tidal Marsh Ecology (Weinstein and Kreeger 2000) through the lens of climate change and the multiple stressor framework. We explore the question: how is climate change expected to impact the trophic linkages between marsh production and estuarine and coastal nekton (free-swimming fishes and invertebrates), now and into the future?

Tidal marshes evolved in dynamic coastal and estuarine settings, and their position at the land-sea interface exposes 
them to a variety of environmental drivers (e.g., ocean currents, watershed hydrology) and environmental gradients (e.g., salinity, temperature, dissolved oxygen; Lauchlan and Nagelkerken 2020). Mounting evidence suggests that some directional, periodic, and stochastic variation in environmental conditions is intensifying under climate change [e.g., global or regional SLR, sea surface temperature (SST), and anomalous droughts, floods, or heatwaves, respectively; Trenberth 2011; Boyd et al. 2015; Nerem et al. 2018]. While coastal and estuarine ecosystems can resist and recover from minor to moderate natural disturbances, multiple stressors interacting synergistically, whereby the combined effects are greater than the sum of the individual (additive) effects, may lead to novel ecological responses (Crain et al. 2008; Jackson et al. 2016) or exceed critical ecological thresholds that result in fundamental state changes (Boström et al. 2011). Quantifying the combined effects of climate-related stressors on costal and estuarine nekton, and their associated fisheries, is of great conservation, restoration, and socio-economic concern (zu Ermgassen et al. this issue; Waltham et al. 2021; Baker et al.
2020; Gilby et al. 2020). Yet disentangling the drivers of change and ecological outcomes remains a major challenge to researchers and managers. We highlight key climate change implications for tidal marshes and food web linkages to estuarine and coastal nekton to inform future studies.

\section{Climate Change Impacts at the Land-Sea Interface}

\section{Coastal Oceans and Watersheds}

Broad-scale climatic changes are already shifting the timing, magnitude, and duration of naturally fluctuating environmental conditions (e.g., SLR, SST, ocean currents, waves, tides, precipitation) in marine, estuarine, and freshwater environments (see Table 1; Pörtner et al. 2014; Haigh et al. 2020; Konapala et al. 2020; Laufkötter et al. 2020). While natural variability is often directional or periodic with an element of stochasticity, climate change can increase the rate of change, amplify extreme
Table 1 Broad-scale environmental drivers to consider for studies addressing the questions: How do climate change-induced shifts in environmental drivers across the marine-freshwater gradient potentially interact? How do these individual drivers or their interactions alter tidal marsh structure, hydrodynamics, water quality, nutrients, vegetation, and ultimately nekton and food webs?

\begin{tabular}{|c|c|c|c|c|c|c|}
\hline \multirow[b]{2}{*}{$\begin{array}{l}\text { Broad-scale } \\
\text { environmental } \\
\text { drivers altered } \\
\text { by climate } \\
\text { change }\end{array}$} & \multicolumn{4}{|l|}{ Coastal ocean } & \multicolumn{2}{|c|}{ Watershed/estuary } \\
\hline & $\begin{array}{l}\text { Ocean currents, waves, } \\
\text { tides, upwelling }\end{array}$ & $\begin{array}{l}\text { Weather, precipitation, } \\
\text { wind, storminess }\end{array}$ & $\begin{array}{l}\text { Sea surface } \\
\text { temperature } \\
(\mathrm{SST}), \text { marine } \\
\text { heatwaves }\end{array}$ & $\begin{array}{l}\text { Relative sea level rise } \\
\text { (RSLR) }\end{array}$ & $\begin{array}{l}\text { Weather, } \\
\text { precipitation, } \\
\text { storminess }\end{array}$ & $\begin{array}{l}\text { Freshwater } \\
\text { flows, } \\
\text { drought vs. } \\
\text { flood }\end{array}$ \\
\hline $\begin{array}{l}\text { Nature of } \\
\text { variation }\end{array}$ & Periodic, stochastic & Periodic, stochastic & $\begin{array}{c}\text { Directional, } \\
\text { periodic, } \\
\text { stochastic }\end{array}$ & Directional & $\begin{array}{l}\text { Periodic, } \\
\text { stochastic }\end{array}$ & $\begin{array}{l}\text { Periodic, } \\
\text { stochas- } \\
\text { tic }\end{array}$ \\
\hline $\begin{array}{l}\text { Marsh structure, } \\
\text { hydrodynami- } \\
\text { cs, water } \\
\text { quality, } \\
\text { nutrients, } \\
\text { vegetation }\end{array}$ & $\begin{array}{l}\text { Hydroperiod, sedimentation, } \\
\text { accretion, erosion, } \\
\text { subsidence, scouring, } \\
\text { vegetation community, } \\
\text { structure, biomass, } \\
\text { growth, temperature, } \\
\text { salinity, turbidity, } \\
\text { dissolved oxygen, pH, } \\
\text { acidification, nutrient } \\
\text { loading }\end{array}$ & $\begin{array}{l}\text { Hydroperiod, coastal } \\
\text { flooding, marsh pore } \\
\text { water exchange, } \\
\text { sediment delivery and } \\
\text { exchange, accretion, } \\
\text { erosion, subsidence, } \\
\text { scouring, temperature, } \\
\text { salinity, turbidity, } \\
\text { dissolved oxygen, pH, } \\
\text { acidification, nutrient } \\
\text { delivery and exchange, } \\
\text { vegetation community, } \\
\text { structure, biomass, } \\
\text { growth }\end{array}$ & $\begin{array}{l}\text { Temperature, } \\
\text { dissolved } \\
\text { oxygen, } \\
\text { vegetation } \\
\text { community, } \\
\text { structure, } \\
\text { biomass, } \\
\text { growth }\end{array}$ & $\begin{array}{l}\text { Hydroperiod, coastal } \\
\text { flooding, sediment } \\
\text { delivery, accretion, } \\
\text { erosion, subsidence, } \\
\text { scouring, vegetation } \\
\text { community, structure, } \\
\text { biomass, growth }\end{array}$ & $\begin{array}{l}\text { Hydroperiod, } \\
\text { flooding, su } \\
\text { runoff, grou } \\
\text { marsh pore } \\
\text { exchange, s } \\
\text { delivery an } \\
\text { accretion, e } \\
\text { scouring, te } \\
\text { salinity, turl } \\
\text { dissolved o } \\
\text { hypoxia, de } \\
\text { nutrient del } \\
\text { exchange, } \\
\text { eutrophicati } \\
\text { algal bloom } \\
\text { community } \\
\text { biomass, gr }\end{array}$ & $\begin{array}{l}\text { river } \\
\text { irface water } \\
\text { undwater and } \\
\text { water } \\
\text { ediment } \\
\text { d exchange, } \\
\text { rosion, } \\
\text { mperature, } \\
\text { bidity, } \\
\text { xygen, } \\
\text { oxygenation } \\
\text { ivery and } \\
\text { ion, harmful } \\
\text { s, vegetation } \\
\text {, structure, } \\
\text { owth }\end{array}$ \\
\hline $\begin{array}{l}\text { Marsh nekton } \\
\text { communities } \\
\text { and food web } \\
\text { dynamics }\end{array}$ & \multicolumn{6}{|c|}{$\begin{array}{l}\text { Species distribution, abundance, biomass, community composition, life history, diversity, species invasions, physiology, phenology, } \\
\text { ontogenetic shifts, migrations, foraging, growth, survival, recruitment, spawning, competition, primary production, food web } \\
\text { pathways, outwelling, secondary production, predator-prey interactions, trophic relays }\end{array}$} \\
\hline
\end{tabular}


events, and shift the timing of variability. As a result, climate change impacts on coastal oceans and watersheds, which influence marshes from seaward and landward directions, respectively, may not only shift in timing individually but also generate simultaneous or consecutive applications of multiple stressors (Crain et al. 2008; Jackson et al. 2016).

Ocean climate variability regulates SST trends, which naturally vary in amplitude and frequency on annual and decadal scales (e.g., Atlantic and Pacific decadal oscillations; Xie and Tanimoto 1998; Mantua and Hare 2002). When viewed over decades, increasing SST is a progressive, directional process; however, departures from long-term averages (i.e., marine heatwaves) occur on daily, monthly, or seasonal timescales (Laufkötter et al. 2020). Coastal watershed hydrology is also regulated by atmospheric climate variability, which influences the timing and magnitude of precipitation, evapotranspiration, and groundwater interactions (Williamson et al. 2009). While long-term averages may be trending in one direction (e.g., drier conditions overall in Mediterranean climates), periodic extremes may also occur (e.g., severe droughts and floods due to changes in seasonal rainfall and snowpack in California, USA; Belmecheri et al. 2016).

Overall, the combined effects of climate change on ocean and watershed processes are connected and poised to interact with each other. This is especially the case in tidal marshes, which are dynamic and structurally complex biogenic habitats that are shaped by tidal and fluvial processes (e.g., tides, surface water runoff, groundwater and marsh porewater exchange; Davis and Dalrymple 2011). Several scenarios suggest that multiple interacting stressors may result in marsh conversion to open water or mudflat (Fagherazzi 2013). For example, the co-occurrence of accelerating regional SLR with increasing frequencies and/or magnitudes of high amplitude "king" tides and storm surges may synergistically worsen flooding and eventually result in marsh drowning (Cayan et al. 2008; Marsooli et al. 2019; Dominicis et al. 2020). Similarly, accelerating regional SLR and seasonal drought interactions may increase the frequency and/or magnitude of salinity intrusion into freshwater/brackish zones in estuaries which has been shown to threaten less salt-tolerant vegetation (Parker et al. 2011; Lauchlan and Nagelkerken 2020). Globally, more frequent and intense deviations from longterm averages and ranges, whether occurring on daily, seasonal, annual, or decadal scales, are likely to lead to novel changes in ecosystem dynamics.

\section{Tidal Marsh Hydrogeomorphology}

Elevation and sediment Marsh surface elevation is the primary factor influencing whether marshes can tolerate and recover from accelerating global or regional SLR impacts due to feedback mechanisms between tidal inundation, above- and belowground plant biomass, and sediment trapping and accretion (Morris et al. 2002; Cahoon et al. 2020). Marshes situated at a higher position within the potential vegetation growth range possess greater "elevation capital" and have a higher capacity to persist under accelerated SLR (Morris et al. 2002; Reed 2002; Cahoon and Guntenspergen 2010; Cahoon et al. 2020). Elevation capital can be maintained if vertical sediment and organic matter accretion rates match or exceed the rate of relative SLR (RSLR), a region-specific measurement of SLR that incorporates vertical land motion (Cahoon 2015). Elevation deficits can occur if marshes experience subsidence, soil erosion, or low sediment supply or plant production, and can be further exacerbated when RSLR exceeds sediment accretion rates (Kirwan and Megonigal 2013). While marshes with high elevation capital can tolerate deficits for long periods (e.g., decades to centuries), marshes with low elevation capital are more vulnerable to threshold effects (or 'tipping points'; see Table 2). That is, they may only be able to persist with deficits for a short period before they deteriorate due to channel expansion, marsh-edge erosion, runaway pond expansion, and/or drowning (Cahoon 2015; Mariotti 2016; Mariotti 2020; Schepers et al. 2020). If accretion rates cannot keep pace with RSLR, marsh migration (or "transgression") into adjacent uplands is the remaining mechanism for the natural maintenance of marsh habitat (Brinson et al. 1995; Kirwan et al. 2016; Schuerch et al. 2018; Kirwan and Gedan 2019). However, marsh migration depends on accommodation space, upland topography, slope, and connectivity, and can be greatly reduced due to shoreline armoring and urbanization, resulting in "coastal squeeze" (see Fig. 1, as well as Pontee 2013; Waltham et al. 2021).

Nutrient dynamics Tidal marsh hydrogeomorphology regulates the exchange of water, sediment, and nutrients across the land-water interface (Davis and Dalrymple 2011), and as a result, multiple interacting stressors may alter organic matter processing, nutrient cycling, and primary productivity (O’Meara et al. 2017). For example, increased rainfall may interact with topography, sediment grain size, and sediment organic matter content to influence the rate and amount of surface water runoff, groundwater and marsh porewater exchange, and ultimately, delivery of upland sediment (Sparks et al. 2014; Sparks et al. 2015). Increased sediment delivery to marshes may then combine with resuspended marsh sediment due to erosion from wave energy to enhance vertical accretion and emergent marsh sustainability (Mudd 2011). However, increased nutrient delivery may counteract this process. For example, nutrient enrichment may alter above- and belowground biomass of saltmarsh cordgrass (Spartina alterniflora; Darby and Turner 2008; Deegan et al. 2012; Hanson et al. 2016) and accelerate microbial decomposition of soil organic matter (Drake et al. 2009; Bulseco et al. 2019). Collectively, these effects can interact synergistically with RSLR and storm surges to physically weaken edges of tidal 
Table 2 Summary of eleven estimates of annual increases in relative sea level rise (RSLR) that, when exceeded, are predicted to lead to the conversion of marsh to open water in each system. Such threshold values are commonly referred to as marsh "tipping points"

\begin{tabular}{|c|c|c|}
\hline $\begin{array}{l}\text { Tipping points } \\
\left(\mathrm{mm}_{\text {year }}{ }^{-1}\right)\end{array}$ & Study description and location & Reference \\
\hline 2 to 10 & Mangrove presence/absence and paleo-botany record in the Pacific & Fujimoto et al. 1996 \\
\hline 4 to 6 & Field observations in New England, USA & Watson et al. 2017 \\
\hline 4 to 10 & $\begin{array}{l}\text { Field experiments and model of high and low sediment marshes on } \\
\text { the East Coast, USA }\end{array}$ & Mudd et al. 2010 \\
\hline 5 & Model based on 5075 samples from 33 salt marshes & Morris et al. 2016 \\
\hline 5 to 10 & $\begin{array}{l}\text { Model of varying tidal ranges and suspended sediment } \\
\text { concentrations on the East and Gulf coasts, USA }\end{array}$ & Kirwan et al. 2010 \\
\hline 5 to 10 & $\begin{array}{l}\text { Determination of the rate of SLR when } 36 \text { deltas formed across the } \\
\text { globe }\end{array}$ & Turner et al. 2018 \\
\hline 6 to 9 & Paleo-marsh record on the Gulf Coast, USA & Törnqvist et al. 2020 \\
\hline 6.1 & $\begin{array}{l}\text { Paleo-record of mangrove vertical accretion records compared to } \\
\text { modeled rates of RSLR at multiple locations globally }\end{array}$ & Saintilan et al. 2020 \\
\hline 7.1 & 780 Holocene evolution reconstructions in Great Britain & Horton et al. 2018 \\
\hline 7.99 & Multiple metrics model on the Gulf Coast, USA & Wu 2019 \\
\hline 8.49 & Total area model on the Gulf Coast, USA & Wu 2019 \\
\hline 12 & Salt marshes with high sedimentation rates on the East Coast, USA & Morris et al. 2002 \\
\hline
\end{tabular}

creeks and increase erosion (Deegan et al. 2012) or to increase the amount of open water due to an increase in the number and size of ponds on the marsh platform (Able this issue). In addition, interactions between nutrients, residence time or tidal flushing, and warming may lead to harmful algal blooms, deoxygenation, and hypoxia (Bricker et al. 2008).

Tidal Marsh Vegetation Plant community structure may respond to climate change in a variety of ways due to speciesspecific anatomical and physiological adaptations (Brinson et al. 1995). Plant species in a low-elevation marsh are adapted to frequent flooding, whereas those in a high-elevation marsh may only tolerate infrequent flooding. As a result, marsh response to an increased hydroperiod (i.e., frequency, duration, and amplitude of tidal flooding) because of RSLR varies depending on the position of the tidal frame. Increased tidal flooding of high marsh vegetation may exceed plant stress tolerances to saltwater inundation and exacerbate soil anoxia, both of which can lead to high marsh plant loss or replacement by low marsh species (Brinson et al. 1995; Fagherazzi 2013).

Marsh response to increased storms and wave energy may also vary. Marshes dominated by structurally rigid plant species may experience folding and breaking of stems, while marshes with more flexible species may tolerate higher wave energy levels, as has been shown with Elymus athericus and Puccinellia maritima, respectively, in a European salt marsh (Rupprecht et al. 2017). However, at very high wave energy levels, conditions may be unsuitable even for highly flexible species, resulting in total plant loss. Positive feedback loops may be exacerbated by climate change, whereby declines in plant density and changes in plant traits can decrease attenuation of wave energy, sediment trapping efficiency, shoreline stabilization, and storm buffering (Temmerman et al. 2005; Möller 2006; Mudd et al. 2010; Ozeren et al. 2014; Morris et al. 2016).

Altered climatic conditions are also predicted to drive changes in foundation species, and the biogenic habitat they provide, in multiple and often non-intuitive ways. Warming-induced increases in the growing season may increase overall community photosynthesis and marsh plant biomass (Gedan and Bertness 2010). While elevated $\mathrm{CO}_{2}$ concentrations may cause a similar overall ecosystem stimulus (Langley et al. 2002), this stimulation may be preferentially beneficial to C3 plants (i.e., forbs), which are currently sub-dominant in many saline marshes, compared to the C4 grasses (e.g., Spartina patens and S. alterniflora) that more commonly dominate those systems (Erickson et al. 2007). "Tropicalization" occurs when decreases in the frequency and duration of extreme cold events allow the expansion of tropical and subtropical macrophytes into temperate areas. For example, woody black mangroves (Avicennia germinans) are replacing S. alterniflora in marshes of the southeastern USA (McKee and Rooth 2008; Cavanaugh et al. 2019). Changing environmental conditions may also affect phenological characteristics such as propagule establishment, peak biomass, senescence, and ultimately marsh surface elevation, as has been observed with increased temperature and shifts in flowering timing in S. alterniflora (Crosby et al. 2015). These types of preferential adaptations may imply substantial shifts in future wetland (i.e., marsh and mangrove) community structure, food web pathways, and fisheries support. 
a
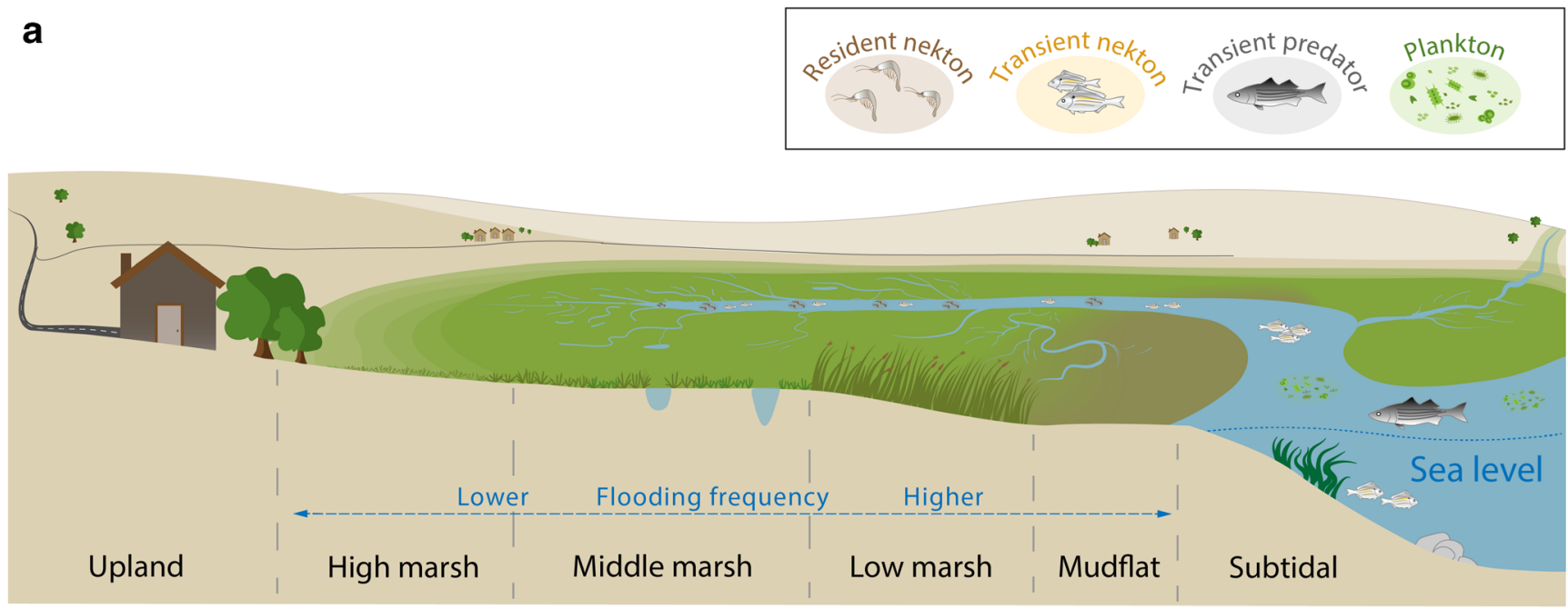

b

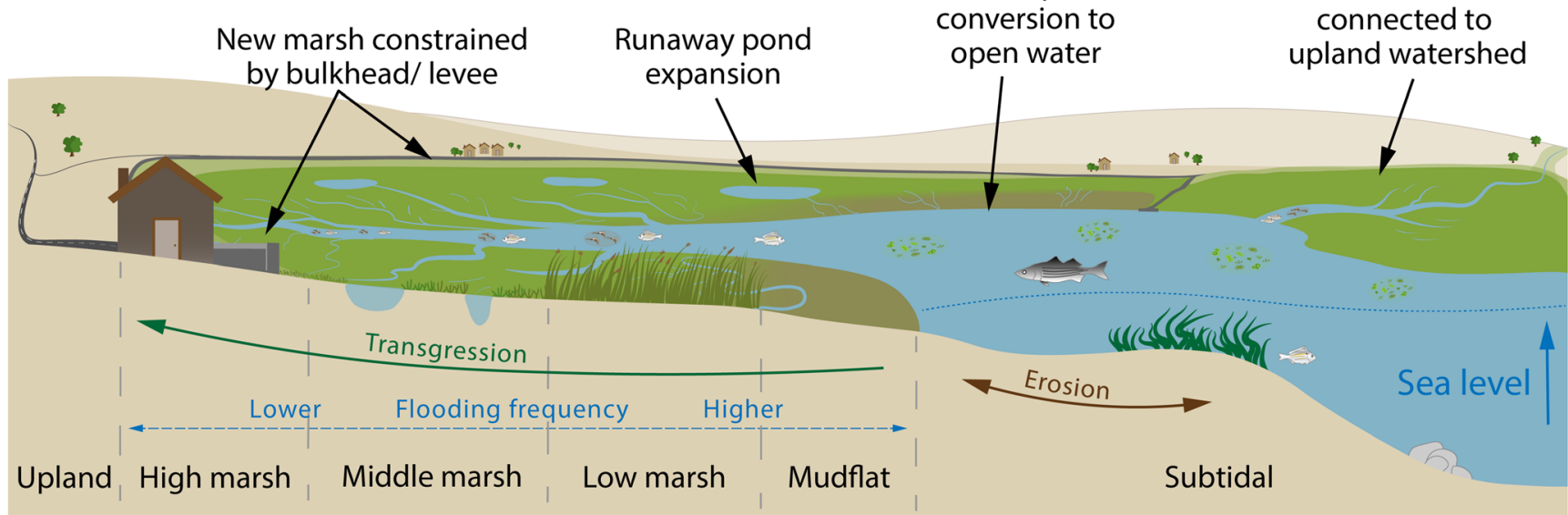

Fig. 1 Comparison of two scenarios: a tidal marsh seascape a under historic rates of sea level rise (SLR) and $\mathbf{b}$ under accelerated SLR. In scenario b, SLR leads to erosion and transgression, which shift the location and extent of each habitat type (e.g., subtidal, mudflat, low marsh, middle marsh, high marsh, ponds) laterally and vertically. In areas where human infrastructure constrains marsh transgression, coastal squeeze leads to a higher risk of flooding along levees, roads,

\section{Climate Change Impacts on Nekton Communities}

Potentially profound consequences of climate change arise from alterations to the complex suite of interacting physical, biogeochemical, and ecological processes affecting estuarine and coastal nekton. Here, we explore multiple stressor impacts on species distributions, life history adaptations, and food web dynamics, with an emphasis on the trophic linkages between marsh production and nekton communities. For example, marine transient primary and intermediate consumers [e.g., juvenile shrimp (Penaeidae) and pinfish (Lagodon rhomboides), respectively] accumulate marsh production while feeding on the marsh surface or in channels before recruiting to estuarine or coastal waters where they are subsequently consumed (Fry and houses. In areas connected to upland watersheds, marsh migration is unimpeded. Implications for food web dynamics in squeezed areas are (1) reduced marsh area for resident nekton and juvenile transient nekton but increased access for larger transient marine predators and (2) shifts in the relative contributions of food web pathways, represented here as a higher biomass of plankton (i.e., phytoplankton and zooplankton) due to expanding open water habitat

et al. 2003). These production transfers or "trophic relays" also occur when larger marine transient predators [e.g., striped bass (Morone saxatilis), white perch (Morone americana)] make "feeding forays" into marshes to consume both resident [e.g., mummichog (Fundulus heteroclitus)] and transient prey (Tupper and Able 2000; Weinstein et al. 2000; Baker et al. 2016). We use this framework (Kneib 2000) to illustrate how trophic relays, the primary mechanism of energy transport from tidal marshes to estuarine and coastal ecosystems, may be fundamentally altered by climate change.

Species Distributions Changes in macroclimate may redistribute species and alter ecosystem function (Thompson et al. 2012). Species range expansions are particularly evident in marine systems (e.g., coastal salt marshes) whereby nekton 
are responding to warming temperatures (Sorte et al. 2010; Burrows et al. 2011; Morley et al. 2020). Historical comparisons of bivalves (Berge et al. 2005), gastropods (Mieszkowska et al. 2006), amphipods (Foster et al. 2004), crabs (Spivak and Luppi 2005; Hollebone and Hay 2007), and fishes (Fodrie et al. 2010; Morson et al. 2012) have all demonstrated poleward expansions. Species distributions within estuaries may expand or contract depending on changes in the spatial and temporal variability of environmental drivers and gradients (e.g., temperature, salinity, dissolved oxygen, pH; Lauchlan and Nagelkerken 2020). In addition, species invasions into new areas may lead to unprecedented combinations of species in estuarine and coastal nekton communities, with unforeseen consequences to species interactions and food web structure (Hobbs et al. 2009).

Life History Adaptations Climate change can affect the phenology, physiology, and behavior of tidal marsh fauna. Plant responses to shifts in the timing and magnitude of environmental fluctuations (e.g., seasonal temperature maxima) may alter the availability of structural habitat (i.e., cover), foraging substrate, and nutritional quality to consumers (Renner and Zohner 2018; Lauchlan and Nagelkerken 2020). In addition, the timing of peak nekton abundance may shift in response to changing environmental conditions. In the southeastern USA, for example, the timing of peak ingress of larval fishes [e.g., Atlantic croaker (Micropogonias undulates), summer flounder (Paralichthys dentatus), pinfish] from the coastal ocean to estuarine nurseries is shifting earlier in warm years, with projections of future shifts in response to warming SST on the order of weeks or months, but is delayed in years with strong northerly winds (Thaxton et al. 2020).

Physiological performance (e.g., growth, calcification, maximum body size), behavior (e.g., predator detection, escape response, freshwater dependence), and inter- and intraspecific competition and non-consumptive indirect effects may also be affected by climate change (Miller et al. 2000; Pörtner and Peck 2010; Nagelkerken and Munday 2016). The consequences may vary among species, depending on life history flexibility (Lord et al. 2017; Lauchlan and Nagelkerken 2020). For example, changes to physiochemical conditions have the potential to negatively affect secondary nekton production directly through changes in feeding rate, growth, and survival [juvenile weakfish (Cynoscion regalis); Lankford and Targett 1994] or indirectly through mediating the overlap of nekton and their predators [age-0 winter flounder (Pseudopleuronectes americanus); Manderson et al. 2006].

Climate change may lead to ecological mismatches between nekton and critical resources at important points in their life cycles, which often occur in pulses or bottlenecks (Lauchlan and Nagelkerken 2020). For example, shifts in the timing of primary production pulses may create a temporal mismatch in feeding and food availability for larval fishes, thus affecting growth and survival (Houde 2016). Altered predator-prey interactions may also impact early survival rates of nekton due to increased predation on newly settled recruits (Almany and Webster 2004), which has the potential to scale up to large effects on population persistence (Levin and Stunz 2005; Baker et al. 2014). Other documented ecological mismatches arise when different life history types, species, or populations exhibit differential responses to spatial or temporal changes in environmental conditions (Durant et al. 2007; Millette et al. 2020). Nekton adapted to moving between marine, estuarine, and freshwater environments at different life stages or events may be uniquely affected by altered timing of their preferred conditions due to climate change (Davis et al. 2014).

Tidal Marsh Food Webs Tidal marsh integration of complex physical, biogeochemical, and ecological processes is reflected in the diversity of primary producers, such as emergent vegetation, phytoplankton, benthic algae, or aquatic macrophytes, which support marsh resident and transient nekton (Currin et al. 1995). Due to the fact that marshes are embedded in seascape mosaics linked by an overlying water column that integrates multiple interacting processes (Childers et al. 2000), consumers that are able to exploit different resources in space and time may be more resilient to change (Young et al. 2020). However, if consumers are reliant on marsh-derived organic matter, a reduction in its availability resulting from marsh plant loss could have cascading effects on nekton growth and recruitment (Litvin and Weinstein 2004; Litvin et al. 2018), foraging success (Colombano et al. 2021), energy reserves (Litvin et al. 2014), and trophic relays (Childers et al. 2000; Deegan et al. 2000; Kneib 2000).

Impacts on biogenic habitat structure may profoundly impact food web dynamics (see Fig. 1). For example, hydroperiod and marsh-edge morphology govern nekton access to the marsh surface, marsh primary production, and prey resources; marsh residence time; and the frequency that organisms are transported off the marsh surface to aquatic habitats (Minello et al. 2012; Ziegler et al. 2020). As a result, any changes to these factors may affect direct consumption of marsh-derived organic matter, feeding forays by transient nekton, and trophic relays (Childers et al. 2000; Deegan et al. 2000; Kneib 2000). Increased tidal flooding height due to RSLR may influence nekton access and predator-prey interactions on the marsh platform, whereby increased flooding duration may affect the amount of marsh production supporting estuarine and coastal food webs (Ziegler et al. 2019). Conversely, marshedge erosion that leads to scarp formations may limit the ability of primary consumers to access the marsh surface during periods of tidal flooding, thus limiting the amount of energy consumers transfer from the marsh surface to the aquatic food web and make available to consumers (Nelson et al. 2019; Lesser et al. 2020). 
Climate change impacts on food web dynamics may also scale up to estuarine and coastal nekton communities and population persistence. Such impacts are already being observed in the Gulf of Mexico, USA, where nekton communities are receiving less energetic benefit from foraging in mangroves, which are increasingly encroaching into marshes due to tropicalization (Harris et al. 2020). Other changes in habitat complexity (e.g., foraging substrate, cover in interstitial spaces) due to climate change and RSLR may reduce the nursery function (i.e., growth and survival of juvenile resident and transient nekton) and, ultimately, reduce recruitment from marshes to adult populations inhabiting other estuarine or marine habitats (Minello et al. 2003; Nagelkerken et al. 2015).

Threshold Effects on Tidal Marsh Food Webs The cumulative impacts of multiple interacting stressors on tidal marshes may yield immediate, delayed, or non-linear responses, or may exceed critical ecological thresholds, with important implications for energy flows to recipient consumers and ecosystems. For example, as seaward marshes submerge under accelerated RSLR, nekton production may increase in response to fragmentation and associated increases in marsh edge-to-area ratios (Minello et al. 1994; Gittman et al. 2018). Therefore, if submergence stimulates nekton production, and transgression compensates for seaward losses, the net effect of RSLR could be an increase in nekton production and consumption by marine transient predators (Chesney et al. 2000). However, these increases in food web support of nekton may only be temporary if significant marsh loss occurs over the long term, with uncertain but potentially catastrophic outcomes for trophic relays from marsh resident to transient nekton (Weinstein et al. 2000). Overall, the resulting net losses of marsh contributions of secondary production to estuarine and coastal food webs may occur over short (e.g., years; Nelson et al. 2019; Harris et al. 2020) or long timescales (e.g., decades, centuries; Able this issue). Understanding what characteristics of tidal marsh ecosystem structure and function underlie nekton support, and their resilience to climate change, is now a clear research and management priority.

\section{Considering Climate Change Impacts in Future Tidal Marsh Research}

Climate change is a rapidly evolving topic that can be incorporated into all tidal marsh research efforts and resource management decisions due to the prevalence and range of effects on present and future tidal marshes globally. Our goals are to promote awareness of climate change impacts and to stimulate discussion among coastal and estuarine scientists and managers. We offer the following recommendations with the aim of encouraging tidal marsh researchers to conduct more holistic and cross-disciplinary climate change studies, which are critically needed for present and future management and conservation of nekton and fisheries that rely on marshes.

- Climate change affects a diverse suite of physical and biological processes that directly and indirectly influence tidal marsh ecosystems. Future studies should focus on drivers of short- and long-term ecosystem change and variability, including those originating from coastal oceans and watersheds (Table 1).

- Research opportunities on climate change impacts on tidal marshes abound, especially in the context of the multiple stressor framework (Table 1) and the critical ecological threshold framework ("tipping points"; Table 2). Quantitative studies on the net effects of multiple stressors will provide important insight into the magnitude, direction, and timing of change that is likely to occur in tidal marsh ecosystems.

- Secondary production offers a composite metric reflecting ecosystem structure and function (Layman and Rypel 2020) and, thus, in the context of this perspective, partially reflects the complex physical, biogeochemical, and ecological processes mediating multiple energetic pathways through which tidal marsh production supports estuarine and coastal nekton. In addition to trophic relays, marsh-derived organic matter exported in the form of particulate or dissolved organic matter may also support nekton (i.e., the "outwelling hypothesis"; Teal 1962; Nixon 1980; Childers et al. 2000; Odum 2000), but this mechanism has received less attention over recent decades (Duarte et al. 2017; Najjar et al. 2018). Studies quantifying tidal marsh energy flows (e.g., $\mathrm{g} \mathrm{m}^{-2}$ year $^{-1}$ ) through both mechanisms are needed to track climate change effects on food web resilience and recovery.

- Advancing integrative research on climate change impacts on tidal marsh ecosystems requires diverse, collaborative teams of theoreticians, empiricists, and statisticians. Open science practices allow for tidal marsh researchers and managers across the globe to tackle pressing climate change issues together (Kimball et al. this issue).

Furthermore, there are numerous other high-priority tidal marsh ecology topics that need to be evaluated in the context of climate change. Examples are listed below.

- Climate change interactions with anthropogenic drivers of seascape change (Gilby et al. 2020)

- Geographic variation in climate change impacts on tidal marsh structure and function (Ziegler et al. 2021)

- Strategies to mitigate the effects of climate change and urbanization through restoration techniques (Waltham et al. 2021) 
- Emerging technologies to study climate change impacts on nekton communities and food web dynamics (Kimball et al. this issue)

- Climate change threats to the provision of marsh-supported fisheries to humans (zu Ermgassen et al. this issue)

Acknowledgments This perspective arose from a meeting held at the Dauphin Island Sea Lab (DISL) 1-3 November 2019 as part of the Coastal and Estuarine Research Federation (CERF) 2019 Conference Workshop Program. The meeting was funded by grants to R. Baker from the University of South Alabama and DISL, and sponsorship from Mississippi-Alabama-, Georgia-, and Washington-Sea Grants, the Grand Bay National Estuarine Research Reserve, the DISL Foundation, and CERF. Additional funding for D. Colombano was provided by the Delta Stewardship Council Delta Science Program administered by California Sea Grant (Award no. 19054). We would like to thank three anonymous reviewers for their helpful comments and also K. Able and A. Ruhi for improving earlier versions of the manuscript.

Open Access This article is licensed under a Creative Commons Attribution 4.0 International License, which permits use, sharing, adaptation, distribution and reproduction in any medium or format, as long as you give appropriate credit to the original author(s) and the source, provide a link to the Creative Commons licence, and indicate if changes were made. The images or other third party material in this article are included in the article's Creative Commons licence, unless indicated otherwise in a credit line to the material. If material is not included in the article's Creative Commons licence and your intended use is not permitted by statutory regulation or exceeds the permitted use, you will need to obtain permission directly from the copyright holder. To view a copy of this licence, visit http://creativecommons.org/licenses/by/4.0/.

\section{References}

Able, K.W. This issue. From cedar cemeteries to marsh lakes: A history of sea level rise in the Mullica Valley. Estuaries and Coasts.

Almany, G.R., and M.S. Webster. 2004. Odd species out as predators reduce diversity of coral-reef fishes. Ecology 85 (11): 2933-2937.

Baker, R., M. Fujiwara, and T.J. Minello. 2014. Juvenile growth and mortality effects on white shrimp Litopenaeus setiferus population dynamics in the northern Gulf of Mexico. Fisheries Research 155: 74-82.

Baker, H.K., J.A. Nelson, and H.M. Leslie. 2016. Quantifying striped bass (Morone saxatilis) dependence on saltmarsh-derived productivity using stable isotope analysis. Estuaries and Coasts 39 (5): 1537 1542.

Baker, R., M.D. Taylor, K.W. Able, M.W. Beck, J. Cebrian, D.D. Colombano, R.M. Connolly, C. Currin, L.A. Deegan, I.C. Feller, B.L. Gilby, M.E. Kimball, T.J. Minello, L.P. Rozas, C. Simenstad, R.E. Turner, N.J. Waltham, M.P. Weinstein, S.L. Ziegler, P.S.E. zu Ermgassen, C. Alcott, S.B. Alford, M. Barbeau, S.C. Crosby, K. Dodds, A. Frank, J. Goeke, L.A. Goodridge Gaines, F.E. Hardcastle, C.J. Henderson, W.R. James, M.D. Kenworthy, J. Lesser, D. Mallick, C.W. Martin, A.E. McDonald, C. McLuckie, B.H. Morrison, J.A. Nelson, G.S. Norris, J. Ollerhead, J.W. Pahl, S. Ramsden, J.S. Rehage, J.F. Reinhardt, R.J. Rezek, L.M. Risse, J.A.M. Smith, E.L. Sparks, and L.W. Staver. 2020. Fisheries rely on threatened salt marshes. Science 370 (6517): 670-671.

Belmecheri, S., F. Babst, E.R. Wahl, D.W. Stahle, and V. Trouet. 2016. Multi-century evaluation of Sierra Nevada snowpack. Nature Climate Change 6 (1): 2-3.
Berge, J., G. Johnsen, F. Nilsen, B. Gulliksen, and D. Slagstad. 2005. Ocean temperature oscillations enable reappearance of blue mussels Mytilus edulis in Svalbard after a 1000 year absence. Marine Ecology Progress Series 303: 167-175.

Boström, C., S.J. Pittman, C. Simenstad, and R.T. Kneib. 2011. Seascape ecology of coastal biogenic habitats: advances, gaps, and challenges. Marine Ecology Progress Series 427: 191-217.

Boyd, P.W., S.T. Lennartz, D.M. Glover, and S.C. Doney. 2015. Biological ramifications of climate-change-mediated oceanic multi-stressors. Nature Climate Change 5 (1): 71-79.

Bricker, S.B., B. Longstaff, W. Dennison, A. Jones, K. Boicourt, C. Wicks, and J. Woerner. 2008. Effects of nutrient enrichment in the nation's estuaries: a decade of change. Harmful Algae 8 (1): 21-32.

Brinson, M.M., R.R. Christian, and L.K. Blum. 1995. Multiple states in the sea-level induced transition from terrestrial forest to estuary. Estuaries 18 (4): 648-659.

Bulseco, A.N., A.E. Giblin, J. Tucker, A.E. Murphy, J. Sanderman, K. Hiller-Bittrolff, and J.L. Bowen. 2019. Nitrate addition stimulates microbial decomposition of organic matter in salt marsh sediments. Global Change Biology 25 (10): 3224-3241.

Burrows, M.T., D.S. Schoeman, L.B. Buckley, P. Moore, E.S. Poloczanska, K.M. Brander, C. Brown, J.F. Bruno, C.M. Duarte, B.S. Halpern, J. Holding, C.V. Kappel, W. Kiessling, M.I. O'Connor, J.M. Pandolfi, C. Parmesan, F.B. Schwing, W.J. Sydeman, and A.J. Richardson. 2011. The pace of shifting climate in marine and terrestrial ecosystems. Science 334 (6056): 652-655.

Cahoon, D.R. 2015. Estimating relative sea-level rise and submergence potential at a coastal wetland. Estuaries and Coasts 38 (3): 10771084.

Cahoon, D., and G. Guntenspergen. 2010. Climate change, sea-level rise, and coastal wetlands. National Wetlands Newsletter 32: 8-12.

Cahoon, D.R., K.L. McKee, and J.T. Morris. 2020. How plants influence resilience of salt marsh and mangrove wetlands to sea-level rise. Estuaries and Coasts.

Cavanaugh, K.C., E.M. Dangremond, C.L. Doughty, A.P. Williams, J.D. Parker, M.A. Hayes, W. Rodriguez, and I.C. Feller. 2019. Climatedriven regime shifts in a mangrove-salt marsh ecotone over the past 250 years. Proceedings of the National Academy of Sciences 116 (43): 21602-21608.

Cayan, D.R., P.D. Bromirski, K. Hayhoe, M. Tyree, M.D. Dettinger, and R.E. Flick. 2008. Climate change projections of sea level extremes along the California coast. Climatic Change 87 (S1): 57-73.

Chesney, E.J., D.M. Baltz, and R.G. Thomas. 2000. Louisiana estuarine and coastal fisheries and habitats: perspectives from a fish's eye view. Ecological Applications 10 (2): 350-366.

Childers, D.L., J.W. Day, and H.N. Mckellar. 2000. Twenty more years of marsh and estuarine flux studies: revisiting Nixon (1980). In Concepts and controversies in tidal marsh ecology, ed. M.P. Weinstein and D.A. Kreeger, 391-423. Dordrecht: Springer Netherlands.

Colombano, D.D., T.B. Handley, T.A. O'Rear, J.R. Durand, and P.B. Moyle. 2021. Complex tidal marsh dynamics structure fish foraging patterns in the San Francisco Estuary. Estuaries and Coasts. https:// doi.org/10.1007/s12237-021-00896-4.

Crain, C.M., K. Kroeker, and B.S. Halpern. 2008. Interactive and cumulative effects of multiple human stressors in marine systems. Ecology Letters 11 (12): 1304-1315.

Crosby, S.C., M. Ivens-Duran, M.D. Bertness, E. Davey, L.A. Deegan, and H.M. Leslie. 2015. Flowering and biomass allocation in U.S. Atlantic coast Spartina alterniflora. American Journal of Botany 102 (5): 669-676.

Currin, C.A., S.Y. Newell, and F.W. Paerl. 1995. The role of standing dead Spartina alterniflora and benthic microalgae in salt marsh food webs: considerations based on multiple stable isotope analysis. Marine Ecology Progress Series 121: 99-116. 
Darby, F.A., and R.E. Turner. 2008. Below- and aboveground biomass of Spartina alterniflora: response to nutrient addition in a Louisiana salt marsh. Estuaries and Coasts 31 (2): 326-334.

Davis, R.A., and R.W. Dalrymple. 2011. Principles of tidal sedimentology. Springer Science \& Business Media.

Davis, B., R. Baker, and M. Sheaves. 2014. Seascape and metacommunity processes regulate fish assemblage structure in coastal wetlands. Marine Ecology Progress Series 500: 187-202.

Deegan, L.A., J.E. Hughes, and R.A. Rountree. 2000. Salt marsh ecosystem support of marine transient species. In Concepts and controversies in tidal marsh ecology, ed. M.P. Weinstein and D.A. Kreeger, 333-365. Dordrecht: Springer Netherlands.

Deegan, L.A., D.S. Johnson, R.S. Warren, B.J. Peterson, J.W. Fleeger, S. Fagherazzi, and W.M. Wollheim. 2012. Coastal eutrophication as a driver of salt marsh loss. Nature 490 (7420): 388-392.

Dominicis, M.D., J. Wolf, S. Jevrejeva, P. Zheng, and Z. Hu. 2020. Future interactions between sea level rise, tides, and storm surges in the world's largest urban area. Geophysical Research Letters 47: e2020GL087002.

Drake, D.C., B.J. Peterson, K.A. Galván, L.A. Deegan, C. Hopkinson, J.M. Johnson, K. Koop-Jakobsen, L.E. Lemay, and C. Picard. 2009. Salt marsh ecosystem biogeochemical responses to nutrient enrichment: a paired ${ }^{15} \mathrm{~N}$ tracer study. Ecology 90 (9): 2535-2546.

Duarte, B., N. Vaz, J.M. Valentim, J.M. Dias, H. Silva, J.C. Marques, N. Sleimi, and I. Caçador. 2017. Revisiting the outwelling hypothesis: modelling salt marsh detrital metal exports under extreme climatic events. Marine Chemistry 191: 24-33.

Durant, J.M., D.Ø. Hjermann, G. Ottersen, and N.C. Stenseth. 2007. Climate and the match or mismatch between predator requirements and resource availability. Climate Research 33: 271-283.

Erickson, J.E., J.P. Megonigal, G. Peresta, and B.G. Drake. 2007. Salinity and sea level mediate elevated $\mathrm{CO}^{2}$ effects on $\mathrm{C} 3-\mathrm{C} 4$ plant interactions and tissue nitrogen in a Chesapeake Bay tidal wetland. Global Change Biology 13 (1): 202-215.

Fagherazzi, S. 2013. The ephemeral life of a salt marsh. Geology 41 (8): 943-944.

Fodrie, F.J., K.L. Heck, S.P. Powers, W.M. Graham, and K.L. Robinson. 2010. Climate-related, decadal-scale assemblage changes of seagrass-associated fishes in the northern Gulf of Mexico. Global Change Biology 16 (1): 48-59.

Foster, J.M., R.W. Heard, and D.M. Knott. 2004. Northern range extensions for Caprella scaura Templeton, 1836 (Crustacea: Amphipoda: Caprellidae) on the Florida Gulf Coast and in South Carolina. Gulf and Caribbean Research 16 (1): 65-69.

Fry, B., D.M. Baltz, M.C. Benfield, J.W. Fleeger, A. Gace, H.L. Haas, and Z.J. Quiñones-Rivera. 2003. Stable isotope indicators of movement and residency for brown shrimp (Farfantepenaeus aztecus) in coastal Louisiana marshscapes. Estuaries 26 (1): 82-97.

Fujimoto, K., T. Miyagi, T. Kikuchi, and T. Kawana. 1996. Mangrove habitat formation and response to Holocene sea-level changes on Kosrae Island, Micronesia. Mangroves and Salt Marshes 1 (1): 47-57.

Gedan, K.B., and M.D. Bertness. 2010. How will warming affect the salt marsh foundation species Spartina patens and its ecological role?. Oecologia 164 (2): 479-487.

Gilby, B. L., M. P. Weinstein, R. Baker, J. Cebrian, S. B. Alford, A. Chelsky, D. Colombano, R. M. Connolly, C. A. Currin, I. C. Feller, and A. Frank. 2020. Human actions alter tidal marsh seascapes and the provision of ecosystem services. Estuaries and Coasts. https://doi.org/10.1007/s12237-020-00830-0.

Gittman, R.K., F.J. Fodrie, C.J. Baillie, M.C. Brodeur, C.A. Currin, D.A. Keller, M.D. Kenworthy, J.P. Morton, J.T. Ridge, and Y.S. Zhang. 2018. Living on the edge: increasing patch size enhances the resilience and community development of a restored salt marsh. Estuaries and Coasts 41 (3): 884-895.
Haigh, I.D., M.D. Pickering, J.A.M. Green, B.K. Arbic, A. Arns, S. Dangendorf, D.F. Hill, K. Horsburgh, T. Howard, D. Idier, and D.A. Jay. 2020. The tides they are a-changin': a comprehensive review of past and future nonastronomical changes in tides, their driving mechanisms, and future implications. Reviews of Geophysics 58: e2018RG000636.

Hanson, A., R. Johnson, C. Wigand, A. Oczkowski, E. Davey, and E. Markham. 2016. Responses of Spartina alterniflora to multiple stressors: changing precipitation patterns, accelerated sea level rise, and nutrient enrichment. Estuaries and Coasts 39 (5): 1376-1385.

Harris, J.M., W.R. James, J.S. Lesser, J.C. Doerr, and J.A. Nelson. 2020. Foundation species shift alters the energetic landscape of marsh nekton. Estuaries and Coasts. https://doi.org/10.1007/s12237-02000852-8.

Hobbs, R.J., E. Higgs, and J.A. Harris. 2009. Novel ecosystems: implications for conservation and restoration. Trends in Ecology \& Evolution 24 (11): 599-605.

Hollebone, A.L., and M.E. Hay. 2007. Population dynamics of the nonnative crab Petrolisthes armatus invading the South Atlantic Bight at densities of thousands $\mathrm{m}^{2}$. Marine Ecology Progress Series 336: 211-223.

Horton, B.P., I. Shennan, S.L. Bradley, N. Cahill, M. Kirwan, R.E. Kopp, and T.A. Shaw. 2018. Predicting marsh vulnerability to sea-level rise using Holocene relative sea-level data. Nature Communications 9: 1-7.

Houde, E.D. 2016. Fish reproductive biology: implications for assessment and management. In, ed. T. Jakobsen, M.J. Fogarty, B.A. Megrey, and E. Moksness. Wiley.

Jackson, M.C., C.J.G. Loewen, R.D. Vinebrooke, and C.T. Chimimba. 2016. Net effects of multiple stressors in freshwater ecosystems: a meta-analysis. Global Change Biology 22 (1): 180-189.

Kimball, M.E., R.M. Connolly, S.B. Alford, D.D. Colombano, W.R James, M.D. Kenworthy, G.S. Norris, J. Ollerhead, S. Ramsden, J.S. Rehage, E.L. Sparks, N.J. Waltham, T.A. Worthington, and M.D. Taylor. This issue. Novel applications of technology for advancing tidal marsh ecology. Estuaries and Coasts.

Kirwan, M.L., and K.B. Gedan. 2019. Sea-level driven land conversion and the formation of ghost forests. Nature Climate Change 9 (6): 450-457.

Kirwan, M.L., and J.P. Megonigal. 2013. Tidal wetland stability in the face of human impacts and sea-level rise. Nature 504 (7478): 53-60.

Kirwan, M.L., G.R. Guntenspergen, A. D'Alpaos, J.T. Morris, S.M. Mudd, and S. Temmerman. 2010. Limits on the adaptability of coastal marshes to rising sea level. Geophysical Research Letters 37 (23): $1-5$

Kirwan, M.L., D.C. Walters, W.G. Reay, and J.A. Carr. 2016. Sea level driven marsh expansion in a coupled model of marsh erosion and migration. Geophysical Research Letters 43 (9): 4366-4373.

Kneib, R.T. 2000. Salt marsh ecoscapes and production transfers by estuarine nekton in the Southeastern United States. In Concepts and controversies in tidal marsh ecology, ed. M.P. Weinstein and D.A. Kreeger, 267-291. Dordrecht: Springer Netherlands.

Konapala, G., A.K. Mishra, Y. Wada, and M.E. Mann. 2020. Climate change will affect global water availability through compounding changes in seasonal precipitation and evaporation. Nature Communications 11: 1-10.

Langley, J.A., B.G. Drake, and B.A. Hungate. 2002. Extensive belowground carbon storage supports roots and mycorrhizae in regenerating scrub oaks. Oecologia 131 (4): 542-548.

Lankford, T.E., and T.E. Targett. 1994. Suitability of estuarine nursery zones for juvenile weakfish (Cynoscion regalis): effects of temperature and salinity on feeding, growth and survival. Marine Biology 119 (4): 611-620.

Lauchlan, S.S., and I. Nagelkerken. 2020. Species range shifts along multistressor mosaics in estuarine environments under future climate. Fish and Fisheries 21 (1): 32-46. 
Laufkötter, C., J. Zscheischler, and T.L. Frölicher. 2020. High-impact marine heatwaves attributable to human-induced global warming. Science 369 (6511): 1621-1625.

Layman, C.A., and A.L. Rypel. 2020. Secondary production is an underutilized metric to assess restoration initiatives. Food Webs 25: $\mathrm{e} 00174$.

Lesser, J.S., C.A. Bechtold, L.A. Deegan, and J.A. Nelson. 2020. Habitat decoupling via saltmarsh creek geomorphology alters connection between spatially-coupled food webs. Estuarine, Coastal and Shelf Science 241: 106825.

Levin, P.S., and G.W. Stunz. 2005. Habitat triage for exploited fishes: can we identify essential "essential fish habitat?". Estuarine, Coastal and Shelf Science 64 (1): 70-78.

Litvin, S.Y., and M.P. Weinstein. 2004. Multivariate analysis of stableisotope ratios to infer movements and utilization of estuarine organic matter by juvenile weakfish (Cynoscion regalis). Canadian Journal of Fisheries and Aquatic Sciences 61 (10): 1851-1861.

Litvin, S.Y., M.P. Weinstein, and V.G. Guida. 2014. Habitat utilization patterns determine the physiological condition of Cynoscion regalis during estuarine residency. Marine Ecology Progress Series 510: 87-99.

Litvin, S.Y., M.P. Weinstein, M. Sheaves, and I. Nagelkerken. 2018. What makes nearshore habitats nurseries for nekton? An emerging view of the nursery role hypothesis. Estuaries and Coasts 41 (6): $1539-1550$.

Lord, J.P., J.P. Barry, and D. Graves. 2017. Impact of climate change on direct and indirect species interactions. Marine Ecology Progress Series 571: 1-11.

Manderson, J.P., J. Pessutti, P. Shaheen, and F. Juanes. 2006. Dynamics of early juvenile winter flounder predation risk on a North West Atlantic estuarine nursery ground. Marine Ecology Progress Series 328: 249-265.

Mantua, N.J., and S.R. Hare. 2002. The Pacific decadal oscillation. Journal of Oceanography 58 (1): 35-44.

Mariotti, G. 2016. Revisiting salt marsh resilience to sea level rise: are ponds responsible for permanent land loss? Journal of Geophysical Research. Earth Surface 121 (7): 1391-1407.

Mariotti, G. 2020. Beyond marsh drowning: the many faces of marsh loss (and gain). Advances in Water Resources 144: 103710.

Marsooli, R., N. Lin, K. Emanuel, and K. Feng. 2019. Climate change exacerbates hurricane flood hazards along US Atlantic and Gulf coasts in spatially varying patterns. Nature Communications 10 : $1-9$.

McKee, K.L., and J.E. Rooth. 2008. Where temperate meets tropical: multi-factorial effects of elevated $\mathrm{CO} 2$, nitrogen enrichment, and competition on a mangrove-salt marsh community. Global Change Biology 14 (5): 971-984.

Mieszkowska, N., M.A. Kendall, S.J. Hawkins, R. Leaper, P. Williamson, N.J. Hardman-Mountford, and A.J. Southward. 2006. Changes in the range of some common rocky shore species in Britain - a response to climate change? Hydrobiologia 555 (1): 241-251.

Miller, J.M., W.H. Neill, K.A. Duchon, and S.W. Ross. 2000. Ecophysiological determinants of secondary production in salt marshes: a simulation study. In Concepts and controversies in tidal marsh ecology, ed. M.P. Weinstein and D.A. Kreeger, 315-331. Dordrecht: Springer Netherlands.

Millette, N.C., J.J. Pierson, and E.W. North. 2020. Water temperature during winter may control striped bass recruitment during spring by affecting the development time of copepod nauplii. ICES Journal of Marine Science 77 (1): 300-314.

Minello, T.J., R.J. Zimmerman, and R. Medina. 1994. The importance of edge for natant macrofauna in a created salt marsh. Wetlands 14 (3): 184-198.

Minello, T.J., K.W. Able, M.P. Weinstein, and C.G. Hays. 2003. Salt marshes as nurseries for nekton: testing hypotheses on density, growth and survival through meta-analysis. Marine Ecology Progress Series 246: 39-59.

Minello, T.J., L.P. Rozas, and R. Baker. 2012. Geographic variability in salt marsh flooding patterns may affect nursery value for fishery species. Estuaries and Coasts 35 (2): 501-514.

Möller, I. 2006. Quantifying saltmarsh vegetation and its effect on wave height dissipation: results from a UK East coast saltmarsh. Estuarine, Coastal and Shelf Science 69 (3-4): 337-351.

Morley, J.W., T.L. Frölicher, and M.L. Pinsky. 2020. Characterizing uncertainty in climate impact projections: a case study with seven marine species on the North American continental shelf. ICES Journal of Marine Science 77 (6): 2118-2133.

Morris, J.T., P.V. Sundareshwar, C.T. Nietch, B. Kjerfve, and D.R. Cahoon. 2002. Responses of coastal wetlands to rising sea level. Ecology 83 (10): 2869-2877.

Morris, J.T., D.C. Barber, J.C. Callaway, R. Chambers, S.C. Hagen, C.S. Hopkinson, B.J. Johnson, P. Megonigal, S.C. Neubauer, T. Troxler, and C. Wigand. 2016. Contributions of organic and inorganic matter to sediment volume and accretion in tidal wetlands at steady state. Earth's Future 4 (4): 110-121.

Morson, J.M., E.A. Bochenek, E.N. Powell, and J.E. Gius. 2012. Sex at length of summer flounder landed in the New Jersey recreational party boat fishery. North American Journal of Fisheries Management 32 (6): 1201-1210.

Mudd, S.M. 2011. The life and death of salt marshes in response to anthropogenic disturbance of sediment supply. Geology 39 (5): $511-512$.

Mudd, S.M., A. D'Alpaos, and J.T. Morris. 2010. How does vegetation affect sedimentation on tidal marshes? Investigating particle capture and hydrodynamic controls on biologically mediated sedimentation. Journal of Geophysical Research. Earth Surface: 115.

Nagelkerken, I., and P.L. Munday. 2016. Animal behaviour shapes the ecological effects of ocean acidification and warming: moving from individual to community-level responses. Global Change Biology 22 (3): 974-989.

Nagelkerken, I., M. Sheaves, R. Baker, and R.M. Connolly. 2015. The seascape nursery: a novel spatial approach to identify and manage nurseries for coastal marine fauna. Fish and Fisheries 16 (2): 362 371.

Najjar, R.G., M. Herrmann, R. Alexander, E.W. Boyer, D.J. Burdige, D. Butman, W.J. Cai, E.A. Canuel, R.F. Chen, M.A. Friedrichs, and R.A. Feagin. 2018. Carbon budget of tidal wetlands, estuaries, and shelf waters of Eastern North America. Global Biogeochemical Cycles 32 (3): 389-416.

Nelson, J.A., D.S. Johnson, L.A. Deegan, A.C. Spivak, and N.R. Sommer. 2019. Feedbacks between nutrient enrichment and geomorphology alter bottom-up control on food webs. Ecosystems 22 (2): 229-242.

Nerem, R.S., B.D. Beckley, J.T. Fasullo, B.D. Hamlington, D. Masters, and G.T. Mitchum. 2018. Climate-change-driven accelerated sealevel rise detected in the altimeter era. Proceedings of the National Academy of Sciences 115 (9): 2022-2025.

Nixon, S.W. 1980. Between coastal marshes and coastal waters - a review of twenty years of speculation and research on the role of salt marshes in estuarine productivity and water chemistry. In Estuarine and wetland processes: with emphasis on modeling, ed. P. Hamilton and K.B. Macdonald, 437-525. Boston: Springer US.

O'Meara, T.A., J.R. Hillman, and S.F. Thrush. 2017. Rising tides, cumulative impacts and cascading changes to estuarine ecosystem functions. Scientific Reports 7 (1): 10218.

Odum, E.P. 2000. Tidal marshes as outwelling/pulsing systems. In Concepts and controversies in tidal marsh ecology, ed. M.P. Weinstein and D.A. Kreeger, 3-7. Dordrecht: Springer Netherlands.

Ozeren, Y., D.G. Wren, and W. Wu. 2014. Experimental investigation of wave attenuation through model and live vegetation. Journal of 
Waterway, Port, Coastal, and Ocean Engineering 140 (5): 04014019.

Parker, V.T., J.C. Callaway, L.M. Schile, M.C. Vasey, and E.R. Herbert. 2011. Climate change and San Francisco Bay-Delta tidal wetlands. San Francisco Estuary and Watershed Science 9 (3).

Pontee, N. 2013. Defining coastal squeeze: a discussion. Ocean and Coastal Management 84: 204-207.

Pörtner, H.O., and M.A. Peck. 2010. Climate change effects on fishes and fisheries: towards a cause-and-effect understanding. Journal of Fish Biology 77 (8): 1745-1779.

Pörtner, H.O., D.M. Karl, P.W. Boyd, W. Cheung, S.E. Lluch-Cota, Y. Nojiri, D.N. Schmidt, P.O. Zavialov, J. Alheit, J. Aristegui, C. Armstrong, G. Beaugrand, V. Belkovich, C. Bowler, P. Brewer, M. Church, S.R. Cooley, P. del Monte-Luna, M. Edwards, M. Flint, M.J. Follows, T. Frölicher, E.A. Fulton, J.P. Gattuso, O. Hoegh-Guldberg, E.E. Hofmann, A.H. Knoll, L.A. Levin, L. Menzel, C.L. Moloney, R.I. Perry, E.S. Poloczanska, J.M. Roberts, B. Rost, J.L. Sarmiento, K. Sedlacek, D. Storch, C. Wienecke, and A.C. Wittman. 2014. Ocean Systems. Climate change 2014: impacts, adaptation, and vulnerability. Part A: global and sectoral aspects. Contribution of working group II to the fifth assessment report of the Intergovernmental Panel on Climate Change. Cambridge: Cambridge University Press.

Przeslawski, R., M. Byrne, and C. Mellin. 2015. A review and metaanalysis of the effects of multiple abiotic stressors on marine embryos and larvae. Global Change Biology 21 (6): 2122-2140.

Reed, D.J. 2002. Sea-level rise and coastal marsh sustainability: geological and ecological factors in the Mississippi delta plain. Geomorphology 48 (1-3): 233-243.

Renner, S.S., and C.M. Zohner. 2018. Climate change and phenological mismatch in trophic interactions among plants, insects, and vertebrates. Annual Review of Ecology, Evolution, and Systematics 49 (1): $165-182$.

Rupprecht, F., I. Möller, M. Paul, M. Kudella, T. Spencer, B.K. van Wesenbeeck, G. Wolters, K. Jensen, T.J. Bouma, M. MirandaLange, and S. Schimmels. 2017. Vegetation-wave interactions in salt marshes under storm surge conditions. Ecological Engineering 100: 301-315.

Saintilan, N., N.S. Khan, E. Ashe, J.J. Kelleway, K. Rogers, C.D. Woodroffe, and B.P. Horton. 2020. Thresholds of mangrove survival under rapid sea level rise. Science 368 (6495): 1118-1121.

Schepers, L., P. Brennand, M.L. Kirwan, G.R. Guntenspergen, and S. Temmerman. 2020. Coastal marsh degradation into ponds induces irreversible elevation loss relative to sea level in a microtidal system. Geophysical Research Letters 47: e2020GL089121.

Schuerch, M., T. Spencer, S. Temmerman, M.L. Kirwan, C. Wolff, D. Lincke, C.J. McOwen, M.D. Pickering, R. Reef, A.T. Vafeidis, and J. Hinkel. 2018. Future response of global coastal wetlands to sealevel rise. Nature 561 (7722): 231-234.

Sorte, C.J.B., S.L. Williams, and J.T. Carlton. 2010. Marine range shifts and species introductions: comparative spread rates and community impacts. Global Ecology and Biogeography 19 (3): 303-316.

Sparks, E.L., J. Cebrian, and S.M. Smith. 2014. Removal of fast flowing nitrogen from marshes restored in sandy soils. PLoS ONE 9 (10): e111456.

Sparks, E.L., J. Cebrian, C.R. Tobias, and C.A. May. 2015. Groundwater nitrogen processing in Northern Gulf of Mexico restored marshes. Journal of Environmental Management 150: 206-215.

Spivak, E.D., and T.A. Luppi. 2005. Southern range extension of two western Atlantic intertidal mud crabs: Panopeus meridionalis Williams, 1984 and Eurypanopeus depressus Smith, 1869
(Crustacea: Brachyura: Panopeidae) in Argentinian waters. Proceedings of the Biological Society of Washington 118 (3): 551-557.

Teal, J.M. 1962. Energy flow in the salt marsh ecosystem of Georgia. Ecology 43 (4): 614-624.

Temmerman, S., T.J. Bouma, G. Govers, Z.B. Wang, M.B.D. Vries, and P.M.J. Herman. 2005. Impact of vegetation on flow routing and sedimentation patterns: three-dimensional modeling for a tidal marsh. Journal of Geophysical Research 110 (F4).

Thaxton, W.C., J.C. Taylor, and R.G. Asch. 2020. Climate-associated trends and variability in ichthyoplankton phenology from the longest continuous larval fish time series on the east coast of the United States. Marine Ecology Progress Series 650: 269-287.

Thompson, R.M., U. Brose, J.A. Dunne, R.O. Hall, S. Hladyz, R.L. Kitching, N.D. Martinez, H. Rantala, T.N. Romanuk, D.B. Stouffer, and J.M. Tylianakis. 2012. Food webs: reconciling the structure and function of biodiversity. Trends in Ecology \& Evolution 27 (12): 689-697.

Törnqvist, T.E., K.L. Jankowski, Y.X. Li, and J.L. González. 2020. Tipping points of Mississippi Delta marshes due to accelerated sea-level rise. Science Advances 6: eaaz5512.

Trenberth, K.E. 2011. Changes in precipitation with climate change. Climate Research 47 (1): 123-138.

Tupper, M., and K.W. Able. 2000. Movements and food habits of striped bass (Morone saxatilis) in Delaware Bay (USA) salt marshes: comparison of a restored and a reference marsh. Marine Biology 137 (56): 1049-1058.

Turner, R.E., M.S. Kearney, and R.W. Parkinson. 2018. Sea-level rise tipping point of delta survival. Journal of Coastal Research 34: 470-474.

Waltham, N. J., C. Alcott, M. Barbeau, J. Cebrian, R. Connolly, L. Deegan, K. Dodds, L. Gaines, B. Gilby, C. Henderson, C. McLuckie, T. Minello, G. Norris, J. Ollerhead, J. Pahl, J. Reinhardt, R. Rezek, C. A. Simenstad, J. Smith, E. Sparks, L. Staver, M. P. Weinstein, and S. L. Ziegler. 2021. Tidal marsh restoration optimism in a changing climate and urbanizing seascape. Estuaries and Coasts. https://doi.org/10.1007/s12237-020-00875-1.

Watson, E.B., C. Wigand, E.W. Davey, H.M. Andrews, J. Bishop, and K.B. Raposa. 2017. Wetland loss patterns and inundationproductivity relationships prognosticate widespread salt marsh loss for Southern New England. Estuaries and Coasts 40 (3): 662-681.

Weinstein, M.P., and D.A. Kreeger, eds. 2000. Concepts and controversies in tidal marsh ecology. Springer Science \& Business Media.

Weinstein, M.P., K.R. Philipp, and P. Goodwin. 2000. Catastrophes, near-catastrophes and the bounds of expectation: success criteria for macroscale marsh restoration. In Concepts and controversies in tidal marsh ecology, ed. M.P. Weinstein and D.A. Kreeger, 777 804. Dordrecht: Springer Netherlands.

Williamson, C.E., J.E. Saros, W.F. Vincent, and J.P. Smol. 2009. Lakes and reservoirs as sentinels, integrators, and regulators of climate change. Limnology and Oceanography 54 (6part2): 2273-2282.

Wu, W. 2019. Accounting for spatial patterns in deriving sea-level rise thresholds for salt marsh stability: more than just total areas? Ecological Indicators 103: 260-271.

Xie, S.P., and Y. Tanimoto. 1998. A pan-Atlantic decadal climate oscillation. Geophysical Research Letters 25 (12): 2185-2188.

Young, M., E. Howe, T. O'Rear, K. Berridge, and P. Moyle. 2020. Food web fuel differs across habitats and seasons of a tidal freshwater estuary. Estuaries and Coasts: 1-16. 
Ziegler, S.L., K.W. Able, and F.J. Fodrie. 2019. Dietary shifts across biogeographic scales alter spatial subsidy dynamics. Ecosphere 10: e02980.

Ziegler, S.L., M.D. Miller, C.S. Smith, and F.J. Fodrie. 2020. Abiotic cycles mediate the strength of cross-boundary consumption within coastal food webs. Estuaries and Coasts: 1-10.

Ziegler, S.L., R. Baker, S.C. Crosby, D.D. Colombano, M.A. Barbeau, J. Cebrian, D. Mallick, C.W. Martin, J.A. Nelson, J.F. Reinhardt, C.
Simenstad, N.J. Waltham, T.A. Worthington, and L.P. Rozas. 2021. Geographic variation in salt marsh structure and function for nekton: a guide to finding commonality across multiple scales. Estuaries and Coasts. https://doi.org/10.1007/s12237-020-00894-y.

zu Ermgassen, P. S. E., R. Baker, M. W. Beck, K. Dodds, S. O. S. E. zu Ermgassen, D. Mallick, M. D. Taylor, and R. E. Turner. This issue. Ecosystem services: Delivering decision making for salt marshes. Estuaries and Coasts.

\section{Affiliations}

\section{Denise D. Colombano ${ }^{1}$ D $~ \cdot$ Steven Y. Litvin ${ }^{2}$. Shelby L. Ziegler ${ }^{3}$. Scott B. Alford ${ }^{4}$. Ronald Baker ${ }^{5}$.} Myriam A. Barbeau ${ }^{6}$. Just Cebrián ${ }^{7} \cdot \operatorname{Rod}$ M. Connolly ${ }^{8} \cdot$ Carolyn A. Currin $^{9} \cdot$ Linda A. Deegan $^{10} \cdot$ Justin S. Lesser $^{11}$. Charles W. Martin ${ }^{4}$. Ashley E. McDonald ${ }^{12}$. Catherine McLuckie ${ }^{13}$. Blair H. Morrison ${ }^{5}$. James W. Pahl ${ }^{14}$. L. Mark Risse ${ }^{15} \cdot$ Joseph A. M. Smith ${ }^{16} \cdot$ Lorie W. Staver $^{17} \cdot$ R. Eugene Turner ${ }^{18} \cdot$ Nathan J. Waltham ${ }^{19}$

1 Department of Environmental Science, Policy, and Management, University of California, Berkeley, 130 Mulford Hall \#3114, Berkeley, CA 94720, USA

2 Monterey Bay Aquarium Research Institute, 7700 Sandholdt Rd, Moss Landing, CA 95039, USA

3 Institute of Marine Sciences, University of North Carolina at Chapel Hill, 3431 Arendell Street, Morehead City, NC 28557, USA

4 Nature Coast Biological Station, University of Florida Institute of Food and Agricultural Sciences, 552 1st St, PO Box 878, Cedar Key, FL 32625, USA

5 University of South Alabama, and Dauphin Island Sea Lab, Dauphin Island, AL 36528, USA

6 Department of Biology, University of New Brunswick, PO Box 4400, Fredericton, New Brunswick E3B 5A3, Canada

7 Northern Gulf Institute, Mississippi State University, 1021 Balch Blvd, Stennis Space Center, MS 39529, USA

8 Australian Rivers Institute - Coast \& Estuaries, School of Environment and Science, Griffith University, Gold Coast, Queensland 4222, Australia

9 National Centers for Coastal Ocean Science, National Oceanic and Atmospheric Administration, 101 Pivers Island Rd, Beaufort, NC 28516, USA
10 Woodwell Climate Research Center, 149 Woods Hole Rd, Falmouth, MA 02540, USA

11 University of Louisiana at Lafayette, 410 St. Mary Blvd, Lafayette, LA 70503, USA

12 Texas A\&M University at Galveston, 200 Seawolf Pkwy, Galveston, TX 77554, USA

13 School of Environmental and Life Sciences, University of Newcastle, University Dr, Callaghan, NSW 2308, Australia

14 Louisiana Coastal Protection and Restoration Authority, 150 Terrace Ave, Baton Rouge, LA 70802, USA

15 University of Georgia Marine Extension and Georgia Sea Grant, 1030 Chicopee Complex, Athens, GA 30602, USA

16 US Fish and Wildlife Service, 800 Great Creek Rd, Galloway, NJ 08205, USA

17 Horn Point Laboratory, University of Maryland Center for Environmental Science, 2020 Horn's Point Rd, Cambridge, MD 21617, USA

18 Department of Oceanography and Coastal Sciences, Louisiana State University, Baton Rouge, LA 70803, USA

19 Marine Data Technology Hub, Centre for Tropical Water and Aquatic Ecosystem Research (TropWATER), College of Science and Engineering, James Cook University, Douglas, Queensland 4814, Australia 